Article

\title{
Evaluation of the Copper and Zinc Contents of Soils in the Vineyards of La Rioja (Spain)
}

\author{
Victoria Iñigo ${ }^{1}{ }^{(}$, Alvaro Marín ${ }^{2}{ }^{(}$, Marisol Andrades ${ }^{2}$ and Raimundo Jiménez-Ballesta ${ }^{3, *}$ \\ 1 Department of Mathematical and Experimental Sciences Didactics, La Rioja International University, \\ 26006 Logroño, Spain; victoria.inigo@unir.net. \\ 2 Department of Agriculture and Food, La Rioja University, 26006 Logroño, Spain; \\ aj.m.m@hotmail.com (A.M.); Marisol.andrades@unirioja.es (M.A.) \\ 3 Department of Geology and Geochemistry, Autónoma University, 28049 Madrid, Spain \\ * Correspondence: raimundo.jimenez@uam.es
}

Received: 13 July 2020; Accepted: 25 July 2020; Published: 29 July 2020

check for updates

\begin{abstract}
The aim of this study was to determine the concentrations of $\mathrm{Cu}$ and $\mathrm{Zn}$ in soils in the vineyards of La Rioja and to calculate reference values for the two elements. Samples were taken from the surface horizon $(0-20 \mathrm{~cm})$ and the subsurface horizon $(40-60 \mathrm{~cm})$ in 106 locations. Some physico-chemical properties were analyzed along with the total and bioavailable contents of these elements. Various statistical parameters were calculated, and distribution maps were then created using the ordinary-Kriging method. The Cu content was in the range of $2.46-121.52 \mathrm{mg} \mathrm{kg}^{-1}$, and the $\mathrm{Zn}$ content was $9.05-125.67 \mathrm{mg} \mathrm{kg}^{-1}$. These values fell within the normal ranges in comparison with other areas of Spain and the rest of Europe. The concentrations in the surface and in the subsurface were compared; in the case of $\mathrm{Cu}$, the concentration was higher at the surface, whereas significant differences in the vertical distribution of $\mathrm{Zn}$ were not observed. Both metals had a heterogeneous distribution across the entire area of study. In the case of $\mathrm{Zn}$, the similarity of the maps between surface and depth was verified, while the case of $\mathrm{Cu}$ was different. The main source of these metals was the parent material from which the soil had been formed, but in the case of $\mathrm{Cu}$, maps showed increased $\mathrm{Cu}$ at the surface, which was especially marked at certain points and seemed to indicate the presence of an exogenous contribution at these locations. That means that the copper concentrations in the topsoil resulted from the yearlong grapevine protection with copper-based agents. Reference values were calculated to be 85.28 and $48.88 \mathrm{mg} \mathrm{kg}^{-1}$ of $\mathrm{Cu}$ and 83.69 and $72.05 \mathrm{mg} \mathrm{kg}^{-1}$ for Zn at the surface and at depth, respectively.
\end{abstract}

Keywords: vineyard soils; reference levels; $\mathrm{Cu}$ content; Zn content; $\mathrm{Cu}$ distribution; Zn distribution

\section{Introduction}

Certain heavy metals and other trace elements are natural constituents of soil, since they derive from the bedrock from which the soil has been formed. In particular, copper and zinc are essential for plants, but they become toxic at higher concentrations. Their content is an indicator of possible excesses or deficiencies for plat nutrition and, ultimately, human health.

Hence, soils that are derived from the same parent material usually have similar concentrations of trace elements [1]. This concentration can increase due to natural causes such as leaching processes or due to various anthropogenic sources.

In this regard, special consideration is given to agricultural soils, because the treatments applied to them may affect soil fertility or introduce toxic elements into the human food chain [2]. For this reason, the determination of the concentrations of heavy metals in soils has become the focus of various 
public institutions and has led to the drawing up of several regulations on soil protection, such as Council Directive 86/278/EEC and a set of indicative values for soil contamination in Spain [3].

In many regions, the determination of the concentrations of these metals in soils has been a priority for some time in order to understand and distinguish between the contributions made by the soil's parent material and human activity. Reference values have been established from the determined values, i.e., the thresholds for concentrations above which it can be suggested that there are external contributions and, therefore, signs of contamination $[4,5]$.

The qualified Rioja DOCa (calificada designation of origin) has a high standing in terms of the production and quality of its wines. An important factor in the quality of these wines is the soil in the vineyards. Consequently, it is essential to determine the reference levels for potentially toxic elements in these soils and to subsequently monitor them to ensure ongoing soil fertility and the safety of the wines produced in this region.

In particular, copper and zinc are essential for plants, but they become toxic at higher concentrations. Their content is an indicator of possible excesses or deficiencies for plant nutrition and ultimately human health. The aims of the research described here were to determine the total and bioavailable contents of $\mathrm{Cu}$ and $\mathrm{Zn}$ in soils in the vineyards of La Rioja, both at the surface and at depth, in order to compare their distribution throughout the region and to calculate their reference levels.

\section{Materials and Methods}

\subsection{Area of Study: Rioja DOCa}

The chosen area, Rioja DOCa, is located close to the northern coast of the Iberian Peninsula (Figure 1) and consists of cultivated land that has been subject to various geological and pedological processes. It is a region with a significant amount of cultivation, including market gardens, orchards, and vineyards.

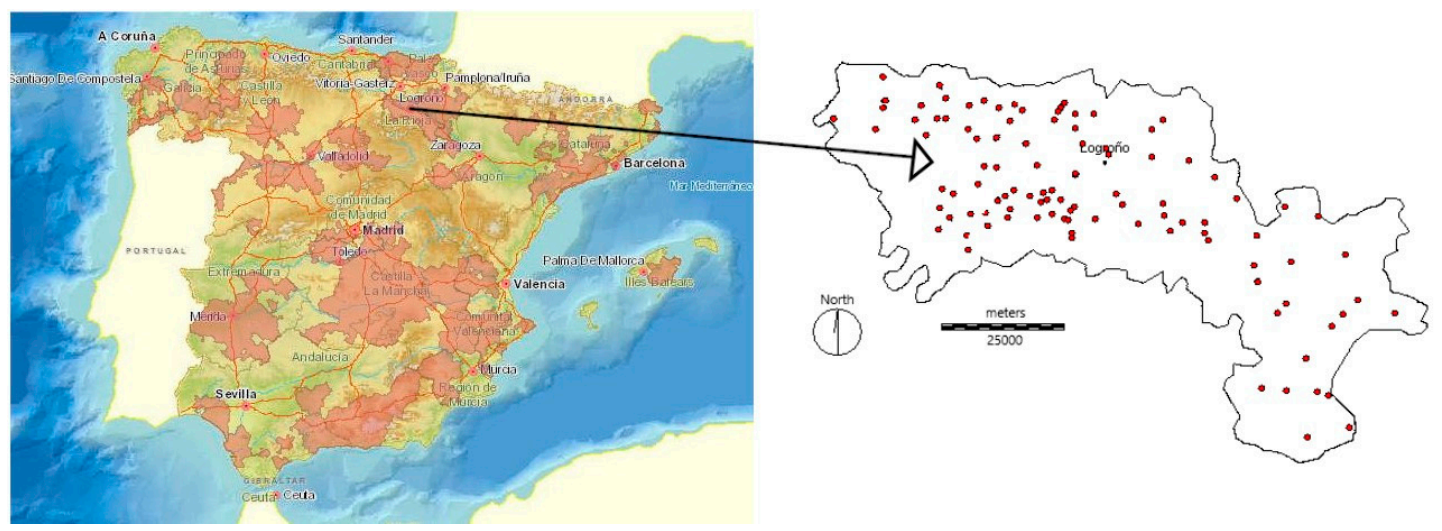

Figure 1. Location map of La Rioja Vineyards in Spanish Vineyards (extracted from https://sig.mapama. gob.es/geoportal/) and location of sample points.

The region is located on the banks of the River Ebro and is divided into three different zones. Rioja Alta is the westernmost region of the area of study and is located on the south bank of the Ebro, with an average altitude of $400-500 \mathrm{~m}$, an Atlantic climate, and calcareous soils. Rioja Baja is the easternmost region and is also located on the south bank of the river. Its elevation is the lowest of the three zones (300-400 m) and its climate is Mediterranean (dry and warm), with soils formed from fluvial materials. Rioja Alavesa is the northernmost area and is located north of the River Ebro at an altitude of 500-700 $\mathrm{m}$, and the soil has a high proportion of calcium carbonate and clays. The average temperature in the three zones is $12-14{ }^{\circ} \mathrm{C}$.

The geological material found in this area mainly consists of sedimentary rocks such as marl, limestone, sandstone, conglomerate, and gypsum (on the terraces and slopes). There are also some 
acidic rocks, often with gravel. Predominantly deriving from limestone and used intensively for vineyards, some soils are located on slope shade lands in the lower section. Some areas are occupied by soils developed in calcareous clay (with more clay and silt than those derived from sandstone) that has a predominantly silty-loam texture, and these areas are usually well or moderately drained; others have been developed primarily in sandstones, with a dominant texture that ranges from sandy loam to loamy sand and being mostly well drained. Sometimes, though vineyard soils are saturated in spring, they may suffer drought stress during summer.

This parent material, along with other soil forming factors, has led to a variety of soils types: Entisols, Inceptisols, Mollisols, Alfisols, and (rarely) Aridisols [6]. The presence of these different soils means that some vineyards have certain chemical and physical limitations (e.g., highly active limestone contents) and require the use of fertilizers [1].

The potential erosion is rated as intermediate due to the development of vineyard soils from alluvial terrain.

\subsection{Sampling}

A total of 106 locations in the described area were chosen at random for sampling. In each selected location, two individual samples were taken using a core sampler; the first sample was representative of the surface (Ap horizon between 0 and $30 \mathrm{~cm}$ ), and the second was taken from the lower layer or subsoil (B or C horizon between 30 and $60 \mathrm{~cm}$ ). Four subsamples were collected to obtain a simple soil.

A total of 212 samples were taken, and the sites were identified using a Garmin eTrex handheld global positioning system (GPS). A map with the locations from which samples were taken is provided in Figure 1.

\subsection{Analytical Methods}

Each soil sample was dried at room temperature to constant weight. The sample was then sieved through a $2 \mathrm{~mm}$ sieve in order to remove the thicker materials. The remainder was carefully mixed until it was homogeneous. Aliquots of these samples were taken to carry out various chemical analyses.

The chemical properties of the soil were analyzed in accordance with the standard procedures used in the soil analysis laboratories at the University of La Rioja. Each sample was analyzed for texture, determining the amount of clay present (soil texture) [7], and the organic matter (OM) content through dichromate digestion based on the Walkley-Black method. The soil $\mathrm{pH}$ was potentiometrically estimated after balancing with $\mathrm{H}_{2} \mathrm{O}$ and $0.1 \mathrm{M} \mathrm{KCl}$ at a ratio of 1:2.5. The calcium carbonate content was determined using a Bernard calcimeter.

For the determination of $\mathrm{Cu}$ and $\mathrm{Zn}$, the soil samples were digested using a mixture of $\mathrm{HNO}_{3} / \mathrm{HClO}_{4} / \mathrm{HF}$, following the procedure described in detail in previous studies [8]. The total concentrations of $\mathrm{Cu}$ and $\mathrm{Zn}$ were analyzed after complete dissolution with the use of graphite furnace atomic absorption spectroscopy in conjunction with a Varian 220FS detector.

Detection limits were calculated as three times the standard deviation of ten blank samples [9]. The limits were $0.08 \mathrm{mg} \mathrm{kg}^{-1}$ for $\mathrm{Cu}$ and $0.06 \mathrm{mg} \mathrm{kg}^{-1}$ for $\mathrm{Zn}$. The bioavailable content was determined using the method developed by [10] through extraction with DTPA (diethylenetriaminepentaacetic acid). Quality control for measurements was ensured by means of duplication.

\subsection{Statistical Methods}

The data obtained from the surface and subsurface horizons were processed separately. Firstly, the Kolmogorov-Smirnov test was used to analyze the normal distribution of each variable. After this test, standard statistical analyses were performed on the mean, standard deviation, maximum, and minimum using SPSS 20 for Windows. A paired mean differences analysis was also carried out to determine if there were any significant differences between the contents at the surface and at depth. The Pearson correlation coefficient between variables was calculated. 
The obtained data were used to calculate distribution semivariograms for each element, and the corresponding distribution maps were created using the ordinary Kriging method [11].

\section{Results and Discussion}

The total metal total content refers to all existing forms of this metal (ions, oxides, metals, and other compounds). Because of this, the content of disposable metal is not the same and depends on multiple factors. The available content of metal is the quantity that a plant or other living form can uptake.

The statistics (number of samples, mean, standard deviation, variance, minimum, and maximum) for the results obtained for the physicochemical properties of the soil and the concentration of $\mathrm{Cu}$ and $\mathrm{Zn}$ in both horizons are presented in Table 1.

Table 1. Statistical values of measured soil properties $\left(\mathrm{pH}, \mathrm{CaCO}_{3}\right.$ : calcium carbonate \%, OM: organic matter \%, and Clay: clay contents \%) and trace elements concentration ( $\mathrm{mg} \mathrm{kg}^{-1}$ ) of the total and plant-available (BIO) $\mathrm{Cu}$ and $\mathrm{Zn}$ contents in 212 vineyard soil samples at the surface (S) and at depth (D). Additionally shown are pedogeochemical baselines (RV), given in $\mathrm{mg} \mathrm{kg}^{-1}$, for $\mathrm{Cu}$ and $\mathrm{Zn}$ in the DOCa Rioja region.

\begin{tabular}{ccccccc}
\hline & Minimum & Maximum & Mean & $\begin{array}{c}\text { Standard } \\
\text { Deviation }\end{array}$ & Variance & $\begin{array}{c}\text { Reference } \\
\text { Values }\end{array}$ \\
\hline $\mathrm{pH}(\mathrm{S})$ & 5.24 & 8.83 & 8.12 & 0.64 & 0.41 & \\
$\mathrm{pH}(\mathrm{D})$ & 5.24 & 8.85 & 8.21 & 0.5 & 0.25 & \\
$\mathrm{CaCO}_{3}(\mathrm{~S})$ & 0 & 51.75 & 20.37 & 14.55 & 211.93 & \\
$\mathrm{CaCO}_{3}$ (D) & 0 & 54.32 & 20.98 & 14.39 & 207.33 & \\
$\mathrm{OM}_{\text {(S) }}$ & 0.1 & 3.24 & 0.9 & 0.54 & 0.68 & \\
$\mathrm{OM}$ (D) & 0 & 3.49 & 1 & 0.8 & 0.68 & \\
$\mathrm{Clay}(\mathrm{S})$ & 1.62 & 49.34 & 20.09 & 9.3 & 86.65 & \\
Clay (D) & 0 & 45.93 & 18.34 & 9.7 & 94.25 & \\
$\mathrm{Cu}$ Total (S) & 2.46 & 121.52 & 33.48 & 23.9 & 571.26 & 85.28 \\
$\mathrm{Cu}$ Total (D) & 6.07 & 96.64 & 20.74 & 14.07 & 198.18 & 48.88 \\
$\mathrm{Cu}$ Bio (S) & 0.11 & 14.79 & 3.46 & 3.4 & 11.59 & \\
$\mathrm{Cu}$ Bio (D) & 0.07 & 13.81 & 1.23 & 2.01 & 4.05 & \\
Zn Total (S) & 9.05 & 125.67 & 46.87 & 18.41 & 339.09 & 83.69 \\
Zn Total (D) & 17.8 & 92.94 & 44.67 & 13.69 & 187.64 & 72.05 \\
Zn Bio (S) & 0.07 & 2.78 & 0.5 & 0.45 & 0.21 & \\
Zn Bio (D) & 0.04 & 1.96 & 0.34 & 0.34 & 0.12 & \\
\hline
\end{tabular}

It can be seen from the results in Table 1 that the variance for clay content was very high, which indicated an appreciable variability in the textures. Significant variations were also observed in the soil $\mathrm{pH}$, which ranged from 5 to 8.8, with a mean of 8.12 at the surface and 8.21 at depth. In contrast, the variance obtained for the organic matter content was very low, as can be seen from the minimum and maximum values at the surface $(0.1 \%$ and $3.24 \%$, respectively, with a mean average of $0.9 \%)$ and at depth $(0 \%$ and $3.5 \%$, respectively, with a mean of $1.0 \%)$. Calcium carbonate was present in most soils at high levels, and these were higher at depth (between $0 \%$ and $51.75 \%$ with a mean average of $20.37 \%$ in the surface horizon and $20.98 \%$ in the deeper horizon).

\subsection{Concentration and Distribution of $\mathrm{Cu}$}

The descriptive statistics for the $\mathrm{Cu}$ and $\mathrm{Zn}$ concentrations are shown in Table 1 (mean, variance, standard deviation, minimum, and maximum). The variance in the concentrations of these elements was also high, which highlighted the great variability in these soils. The $\mathrm{Cu}$ content varied between 2.46 and $121.52 \mathrm{mg} \mathrm{kg}^{-1}$ at the surface, with an average of $33.48 \mathrm{mg} \mathrm{kg}^{-1}$, and between 6.07 and $96.64 \mathrm{mg} \mathrm{kg}^{-1}$ at depth with a mean average of $20.74 \mathrm{mg} \mathrm{kg}^{-1}$. 
The concentration values for $\mathrm{Cu}$ cited in other research from around the world are provided in Table 2. In this case, it can be stated that the values found in this study are within the range of those included in Table 2. A comparison of the values obtained for $\mathrm{Cu}$ in this study with those shown in

Table 2. Concentrations of $\mathrm{Cu}$ and $\mathrm{Zn}$ (average values) cited by other studies given in $\mathrm{mg} \mathrm{kg}^{-1}$.

\begin{tabular}{cccc}
\hline Region & $\mathbf{C u}$ & Zn & Reference \\
\hline La Rioja (Spain) & $3.01-28.68$ & 53.9 & {$[12]$} \\
Galicia (Spain) & $17.7-45.2$ & & {$[13]$} \\
Alicante (Spain) & 10 & 21 & {$[14]$} \\
Spain & 59 & & {$[15]$} \\
Europe & 68.7 & & {$[15]$} \\
Portugal & & 59 & {$[16]$} \\
Carpatos (Romania) & $3.6-12.6$ & $5-136$ & {$[17]$} \\
Piamonte (Italy) & 58.3 & 62 & {$[18]$} \\
India (Sehore and Vidisha) & 178.1 & 85.2 & {$[19]$} \\
World & 50 & & {$[15]$} \\
\hline
\end{tabular}

The values for the mean surface and depth contents differences are provided in Table 3 . The average values obtained for $\mathrm{Cu}$ were slightly higher at the surface (with a difference of $13 \mathrm{mg} \mathrm{kg}^{-1}$ ), although they were similar to those found in non-cultivated soils in La Rioja [12]. This finding 12indicated a contribution that is mainly geological in origin. The fact that there was a greater quantity at the surface and that high values were found in some localized spots (over $80 \mathrm{mg} \mathrm{kg}^{-1}$ ) could be related to the application of plant protection products with high levels of $\mathrm{Cu}$, as suggested by [13]. As stated previously, Garcia-Navarro et al. [1] commented that some vineyard soils require the use of fertilizers due to particular soil characteristics. Nevertheless, the levels of fertilizer applied were never found to exceed the recommended values for environmental protection set out in 86/278/EEC for agricultural soils with $\mathrm{pH}>7\left(210 \mathrm{mg} \mathrm{kg}^{-1}\right)$. It does not seem that external contributions have significantly increased the concentrations of these metals to levels that might be considered contaminating.

Table 3. Mean differences between $\mathrm{S}$ and $\mathrm{D}$ total and bioavailable (B) concentrations of $\mathrm{Cu}$ and $\mathrm{Zn}$.

\begin{tabular}{lcccccccc}
\hline & & Mean & $\begin{array}{c}\text { Standard } \\
\text { Deviation }\end{array}$ & $\begin{array}{c}\text { Standard } \\
\text { Mean Error }\end{array}$ & $\begin{array}{c}\text { 95\% Confidence Interval Difference } \\
\text { Lower }\end{array}$ & Upper & $\begin{array}{c}\text { Sig. } \\
\text { (Bilateral) }\end{array}$ \\
\hline Pair 1 & CuS - CuD & 13.19245 & 26.63001 & 2.58653 & 8.06383 & 18.32107 & 5.1 & 0 \\
\hline Pair 2 & CuBS - CuBD & 2.3 & 3.76475 & 0.36566 & 1.57495 & 3.02505 & 6.29 & 0 \\
\hline Pair 3 & ZnS - ZnD & 2.11132 & 22.67722 & 2.20261 & -2.25604 & 6.47868 & 0.959 & 0.34 \\
\hline Pair 4 & ZnBS - ZnBD & 0.15 & 0.57607 & 0.05595 & 0.03906 & 0.26094 & 2.681 & 0.009 \\
\hline
\end{tabular}

Some variability was observed in the concentration of bioavailable $\mathrm{Cu}$ content, with a range between 0.11 and $14.79 \mathrm{mg} \mathrm{kg}^{-1}$ and a mean average of $3.46 \mathrm{mg} \mathrm{kg}^{-1}$ at the surface and between 0.07 and $13.81 \mathrm{mg} \mathrm{kg}^{-1}$ with a mean average of $1.23 \mathrm{mg} \mathrm{kg}^{-1}$ at depth. The relationship between the bioavailable content and the total content was around $10 \%$ at the surface and $4 \%$ at depth with respect to total $\mathrm{Cu}$. These relationships were low, which indicated that this element was available to be assimilated by plants without oversaturation.

Distribution maps were created for total contents at the surface and at depth, as well as for bioavailable contents of both elements at the surface. These maps are shown in Figure 2 for $\mathrm{Cu}$ and Figure 3 for $\mathrm{Zn}$. The maps were developed using the ordinary Kriging method, which involved the calculation of the omnidirectional variogram and manual adjustment, as recommended in other studies $[11,20]$. The total concentration of $\mathrm{Cu}$ (Figure 2a,b) showed a similar distribution at the surface and at depth, although the latter map also shows a maximum in the Rioja Baja zone that is not present in Figure 2a. The distribution of the bioavailable content at the surface (Figure 2c) was very similar to the distribution of the total content. This finding suggested that the main source of $\mathrm{Cu}$ is the 
parent material, as shown above. However, there are some areas in Figure 2a with maxima that are not observed in Figure $2 b$. This difference can be explained by the external contribution due to the application of fertilizers and other agrochemical products in the vineyard.
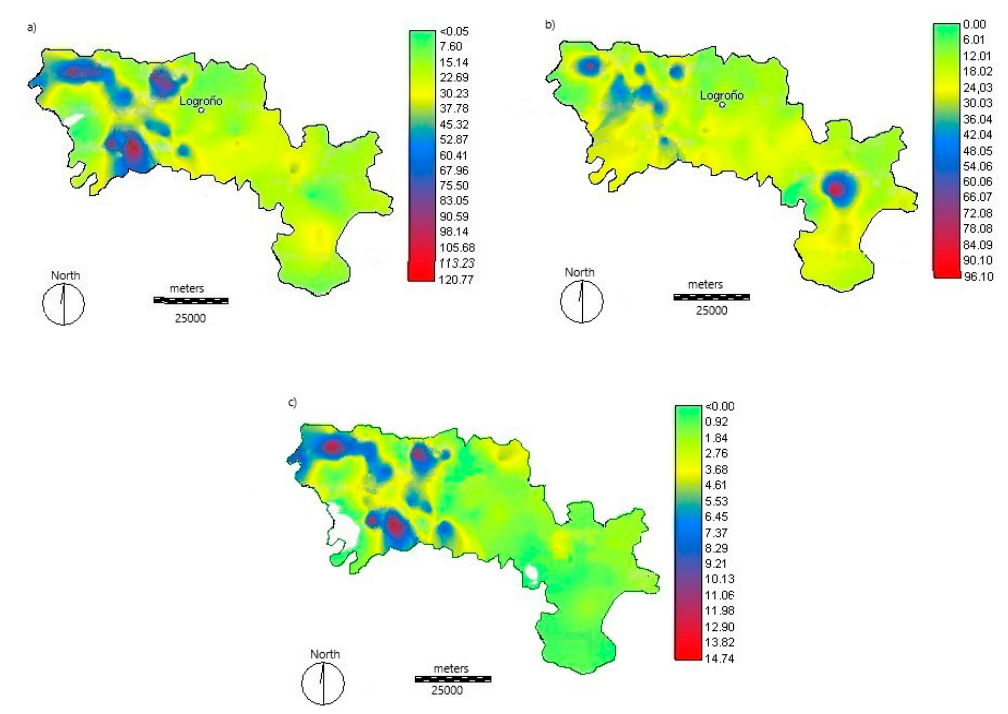

Figure 2. Spatial distribution content of $\mathrm{Cu}$ (arithmetic values in $\mathrm{mg} \mathrm{kg}^{-1}$ ) observed in the vineyard soils of La Rioja: (a) total content in surface, (b) total content in depth, and (c) bioavailable content in surface.

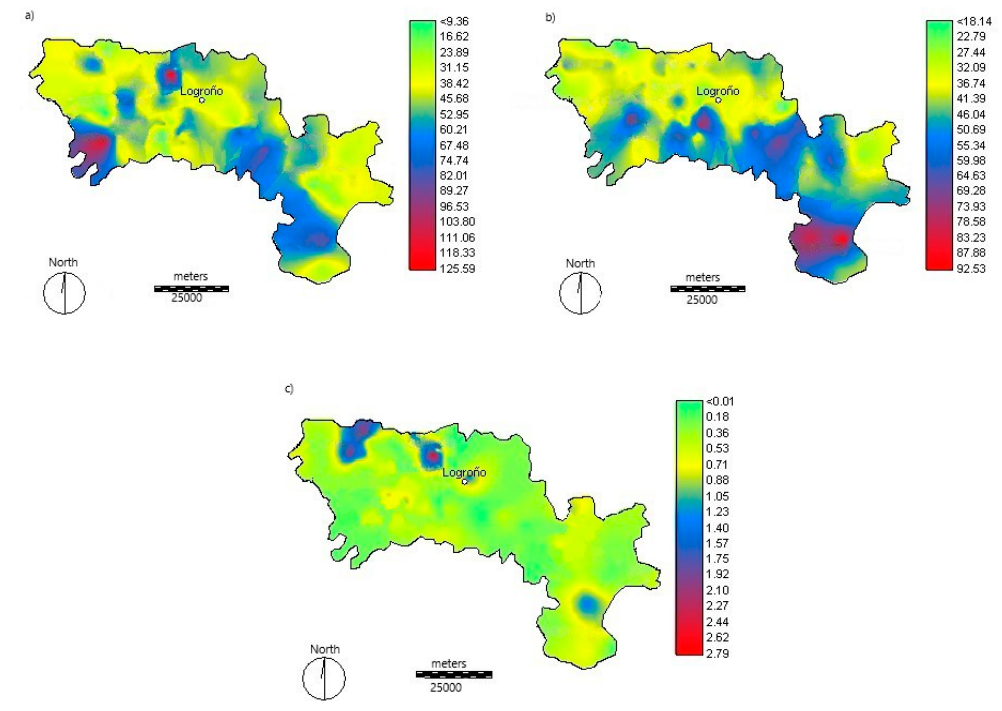

Figure 3. Spatial distribution content of $\mathrm{Zn}$ (arithmetic values in $\mathrm{mg} \mathrm{kg}^{-1}$ ) observed in the vineyard soils of La Rioja: (a) total content in surface, (b) total content in depth, and (c) bioavailable content in surface.

\subsection{Concentration and Distribution of $\mathrm{Zn}$}

The variation in the $\mathrm{Zn}$ concentration was high, albeit with less variability than $\mathrm{Cu}$. The $\mathrm{Zn}$ at the surface ranged from 9.05 to $125.67 \mathrm{mg} \mathrm{kg}^{-1}$ with a mean of $46.87 \mathrm{mg} \mathrm{kg}^{-1}$. At depth, it ranged from 17.8 to $92.94 \mathrm{mg} \mathrm{kg}^{-1}$ with a mean of $46.87 \mathrm{mg} \mathrm{kg}^{-1}$. As in the discussion of $\mathrm{Cu}$, the results from other studies carried out around the world are presented in Table 2. A comparison of the $\mathrm{Zn}$ concentrations with those shown in Table 2 shows that the values were similar to those found in non-cultivated soils in La Rioja [12] and lower than those found in other places.

The spatial variability of the bioavailable $\mathrm{Zn}$ content was lower, with a range between 0.07 and $2.78 \mathrm{mg} \mathrm{kg}^{-1}$ and a mean average of $0.50 \mathrm{mg} \mathrm{kg}^{-1}$ at the surface. At depth, it ranged from 0.04 to 
$1.96 \mathrm{mg} \mathrm{kg}^{-1}$ with a mean average of $0.34 \mathrm{mg} \mathrm{kg}^{-1}$. The relationship between the bioavailable and total content of $\mathrm{Zn}$ was $1 \%$, and it can therefore be stated that the bioavailable $\mathrm{Zn}$ concentration does not represent a potential risk.

It can be seen from the results in Table 3 that significant differences between surface and depth samples were not observed with respect to $\mathrm{Zn}$. Sonoda et al. [21] pointed out the $\mathrm{Zn}$ accumulated in the uppermost soil layer, while [22] showed that soil erosion significantly affected the topsoil $\mathrm{Cu}$ concentrations. This finding suggested that $\mathrm{Zn}$ does not have an external contribution, and its main origin is the parental soil.

The distribution maps for $\mathrm{Zn}$ are shown in Figure 3. Once again, maps were created for total contents at the surface and at depth (Figure $3 a, b)$, along with a map for bioavailable content at the surface (Figure 3c).

The distributions of total contents at the surface and at depth were similar, although the maxima for the two maps are displaced with respect to one another. The bioavailable contents show maxima at the same points in Rioja Alta as the distribution of the total content.

The distribution maps for $\mathrm{Zn}$ show a highly heterogeneous distribution in the surface horizon, both for the total $\mathrm{Zn}$ and the bioavailable $\mathrm{Zn}$. The distribution at the surface shows two maxima in Rioja Alavesa and another in Rioja Alta, while at depth, the maxima are shown to be found in Rioja Baja. The distribution maps for bioavailable $\mathrm{Zn}$ show low values throughout the area of study.

The absence of significant differences between the concentrations at the surface and at depth, the low bioavailability of $\mathrm{Zn}(<1 \%$ of the total content), and the fact that the values are similar to or lower than those found in other studies indicate that the principal contribution for this element is of geological origin.

\subsection{Reference Values}

Having determined the concentrations of $\mathrm{Cu}$ and $\mathrm{Zn}$, the reference values for these metals were calculated with the aim of obtaining the thresholds above which it can be considered that soils are contaminated.

Outlier values were removed from the distribution prior to performing this calculation. A boxplot was drawn for this purpose (Figure $4 \mathrm{a}-\mathrm{d}$ ). On this basis, reference values were calculated according to the formula suggested in the literature $[5,23,24]$ : mean $+2 \times \mathrm{SD}$.
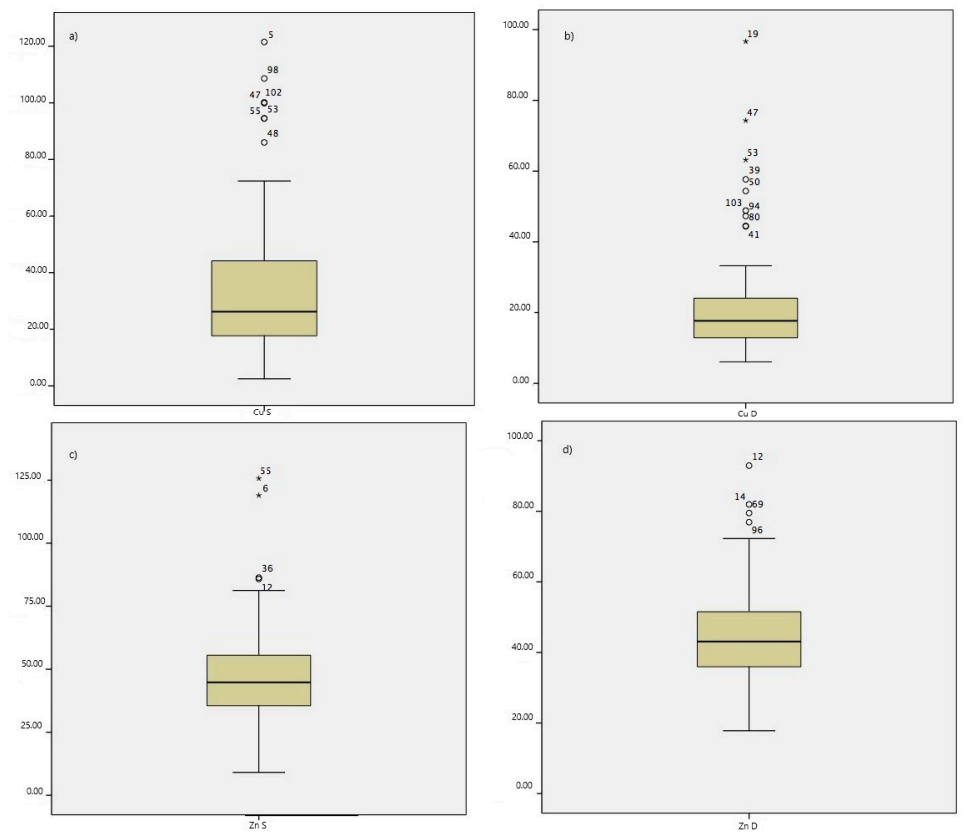

Figure 4. Boxplot of total metal Cu (a) surface and (b) depth and Zn (c) surface and (d) depth. 
The reference values calculated were $85.28 \mathrm{mg} \mathrm{kg}^{-1}$ at the surface and $48.88 \mathrm{mg} \mathrm{kg}^{-1}$ at depth for $\mathrm{Cu}$, and they were calculated as $83.69 \mathrm{mg} \mathrm{kg}^{-1}$ at the surface and $72.05 \mathrm{mg} \mathrm{kg}^{-1}$ at depth for $\mathrm{Zn}$.

\subsection{Statistical Correlations}

The statistical correlations ( $p>0.05$ significance) found for the properties at the concentrations analyzed are provided in Table 4 . There were significant positive correlations between total contents at the surface and at depth for both metals. This finding again suggested that the main contribution of these elements comes from the parent soil.

Table 4. Correlation matrix (surficial horizons). Significative correlation at 0.05 level (bilateral).

\begin{tabular}{cccccc}
\hline & $\mathbf{p H}$ & $\mathrm{CaCO}_{3}$ & $\mathbf{O M}$ & Clay & $\mathbf{C u}$ \\
\hline $\mathrm{CaCO}_{3}$ & 0.296 & & & & \\
\hline $\mathrm{OM}$ & 0.02 & 0.095 & & & \\
\hline $\mathrm{Clay}$ & 0.132 & 0.267 & 0.007 & & \\
\hline $\mathrm{Cu}$ & 0.006 & 0.106 & 0.063 & 0.165 & \\
\hline $\mathrm{Zn}$ & 0.185 & 0.92 & 0.151 & 0.275 & 0.205 \\
\hline
\end{tabular}

A correlation was also found between the organic matter content and the total metal content at the surface, while the $\mathrm{Zn}$ content was also correlated with the clay content. In contrast, $\mathrm{Cu}$ showed a negative correlation with the carbonate and clay contents in both horizons. This trend may be related to the scarcity of clay in limestone rocks [25]. Consequently, it can be suggested that calcium carbonate does not have an impact on the distribution of $\mathrm{Cu}$ in soils.

$\mathrm{Zn}$ shows a positive correlation with the clay content at the surface. The bioavailable content of $\mathrm{Zn}$, on the other hand, shows a negative correlation with clay content. The correlation between the $\mathrm{Cu}$ and $\mathrm{Zn}$ concentrations and the clay content also suggests that the $\mathrm{Cu}$ and $\mathrm{Zn}$ concentrations are mainly derived from the bedrock, as discussed in other publications and for in land cultivated over long periods of time $[25,26]$.

While the main concentration of $\mathrm{Cu}$ was found to arise from the parent material, with the highest concentration in the surface, the positive correlation between this metal, its bioavailable content, and the organic matter content should be noted. The results of numerous studies have suggested that the intensive use of fertilizers and agrochemicals can lead to the accumulation of trace metals in the soil $[25,26]$ and that this can usually be correlated with organic matter content, as observed in the study reported here [27].

There are specific areas in which there was an increase in both $\mathrm{Cu}$ and $\mathrm{Zn}$ values at the surface, as can be seen from the maximum values (Figures $2 a$ and $3 a$ ). It is probable that the favorable climate of La Rioja means that large quantities of agrochemical products are not required in most cases. Nevertheless, the high concentrations found in certain locations suggest that some areas have been subject to the excessive application of $\mathrm{Cu}$-based formulations, such as organic fertilizers and fungicides, as suggested by other authors $[13,20,22,25,28]$.

From the data obtained-and having verified that the concentrations of $\mathrm{Cu}$ and $\mathrm{Zn}$ in the soils originate from the parent material-the reference values for $\mathrm{Cu}$ and $\mathrm{Zn}$ concentrations in the analyzed soils were calculated (Table 1). These values can be used in subsequent studies to determine whether there are external sources of the elements in question and how they affect the soils.

\section{Conclusions}

The concentrations of $\mathrm{Cu}$ and $\mathrm{Zn}$ were similar to other levels of these elements found in studies in Spain and around the world. The distribution maps and mean statistical differences showed that the main origin of these metals was the parent material. Despite the fact that the $\mathrm{Cu}$ concentration 
was higher in the surface, the surface map did indicate higher concentrations in certain spots, and this indicates some external contribution. The relationships between the bioavailable contents and total contents support the above conclusion. In addition, these percentages were low, and this indicates that there is no potential risk to human health.

Reference values for the concentrations of $\mathrm{Cu}$ and $\mathrm{Zn}$ were calculated so that it will be possible in future studies to assess if there is any external contribution to these elements. The reference values were $85.28 \mathrm{mg} \mathrm{kg}^{-1}$ at the surface and $48.88 \mathrm{mg} \mathrm{kg}^{-1}$ at depth for $\mathrm{Cu}$, and they were $83.69 \mathrm{mg} \mathrm{kg}^{-1}$ at the surface and $72.05 \mathrm{mg} \mathrm{kg}^{-1}$ at depth for $\mathrm{Zn}$.

Author Contributions: All authors wrote the paper, contributing by writing different sections of the work. V.I., A.M. and M.A. worked together to do the field research sampling and to analyze the data. R.J.-B. conceived the activities, designed the activities, and wrote about the geological and pedological data. All authors have equally participated in the revisions and the final editing of this text prior to its submission. All authors have read and agreed to the published version of the manuscript.

Funding: This Research was funded by Regional Government of La Rioja (Gobierno de La Rioja, Spain).

Acknowledgments: The authors are grateful to the Regional Government of La Rioja (Spain) for providing financial assistance.

Conflicts of Interest: The authors declare no conflict of interest.

\section{References}

1. García-Navarro, F.J.; Ortiz-Villajos, J.A.A.; Jiménez, C.J.S.; Ballesta, R.J. Red soil geochemistry in a semiarid Mediterranean environment and its suitability for vineyards. Environ. Geochem. Health 2010, 33, $279-289$. [CrossRef]

2. Mahmoud, E.K.; Ghoneim, A.M. Effect of polluted water on soil and plant contamination by heavy metals in El-Mahla El-Kobra, Egypt. Solid Earth 2016, 7, 703-711. [CrossRef]

3. Ihobe, S.A. Valores Indicativos de Evaluación (VIE-B, VIE-C) Para la Protección de los Ecosistemas; Eusko Jaurlaritza/Gobierno Vasco: Vitoria-Gasteiz, Spain, 1998.

4. Beygi, M.; Jalali, M. Assessment of trace elements $(\mathrm{Cd}, \mathrm{Cu}, \mathrm{Ni}, \mathrm{Zn})$ fractionation and bioavailability in vineyard soils from the Hamedan, Iran. Geoderma 2019, 337, 1009-1020. [CrossRef]

5. Ballesta, R.J.; Bueno, P.C.; Rubi, J.A.M.; Giménez, R.G. Pedo-geochemical baseline content levels and soil quality reference values of trace elements in soils from the Mediterranean (Castilla La Mancha, Spain). Open Geosci. 2010, 2, 441-454. [CrossRef]

6. Soil Survey Staff. Keys to Soil Taxonomy, 12th ed.; USDA-Natural Resources Conservation Service: Washington, DC, USA, 2014.

7. Black, C.; Day, P.R. Particle Fractionation and Particle-Size Analysis; American Society of Agronomy: Madison, WI, USA, 1965; pp. 545-567.

8. Mulchi, C.L.; Adamu, C.A.; Chaney, R.L.; Bell, P.F. Residual heavy metal concentrations in sludge amended coastal plain soils. Comparison of extractants 1. Commun. Soil Sci. Plant Anal. 1991, 22, 919-941. [CrossRef]

9. Tuzen, M. Determination of heavy metals in soil, mushroom and plant samples by atomic absorption spectrometry. Microchem. J. 2003, 74, 289-297. [CrossRef]

10. Lindsay, W.L.; Norvell, W.A. Development of a DTPA Soil Test for Zinc, Iron, Manganese, and Copper. Soil Sci. Soc. Am. J. 1978, 42, 421-428. [CrossRef]

11. Isaaks, E.H.; Srivastava, R.M. An Introductuion to Apllied Geostatistics; Oxford University Press: Oxford, UK, 1989.

12. Íñigo, V.; Andrades, M.S.; Alonso-Martirena, J.; Marin, A.; Ballesta, R.J. Background values and distribution trends of $\mathrm{Cu}$ and $\mathrm{Zn}$ in soils of humid Mediterranean environment. Chem. Ecol. 2013, 30, 252-266. [CrossRef]

13. Gómez-Armesto, A.; Carballeira-Díaz, J.; Pérez-Rodríguez, P.; Fernández-Calviño, D.; Arias-Estévez, M.; Nóvoa-Muñoz, J.C.; Álvarez-Rodríguez, E.; Fernández-Sanjurjo, M.J.; Núñez-Delgado, A. Copper content and distribution in vineyard soils from Betanzos (A Coruña, Spain). SJSS 2015, 5, 60-71. [CrossRef]

14. Pedreño, J.N.; Almendro-Candel, M.B.; Lucas, I.G.; Vidal, M.M.J.; Borras, J.B.; Zorpas, A.A. Trace Metal Content and Availability of Essential Metals in Agricultural Soils of Alicante (Spain). Sustainability 2018, 10, 4534. [CrossRef] 
15. Adriano, D.C. Trace Elements in Terrestrial Environments: Biogeochemistry, Bioavailability, and Risks of Metals, 2nd ed.; Springer: New York, NY, USA, 2001.

16. Ferreira, L.; Inácio, M.; Morgado, P.; Batista, M.J.; Ferreira, A.; Pereira, V.; Pinto, M. Low-density geochemical mapping in Portugal. Appl. Geochem. 2001, 16, 1323-1331. [CrossRef]

17. Donisa, C.; Mocanu, R.; Steinnes, E.; Vasu, A. Heavy Metal Pollution by Atmospheric Transport in Natural Soils from the Northern Part of Eastern Carpathians. Water Air Soil Pollut. 2000, 120, 347-358. [CrossRef]

18. Facchinelli, A.; Sacchi, E.; Mallen, L. Multivariate statistical and GIS-based approach to identify heavy metal sources in soils. Environ. Pollut. 2001, 114, 313-324. [CrossRef]

19. Rajendiran, S.; Singh, T.B.; Saha, J.K.; Coumar, M.V.; Dotaniya, M.L.; Kundu, S.; Patra, A.K. Spatial Distribution and Baseline Concentration of Heavy Metals in Swell-Shrink Soils of Madhya Pradesh, India. Water Sci. Technol. Libr. 2017, 77, 135-145. [CrossRef]

20. Baran, A.; Jerzy, W.; Mazurek, R.; Urbański, K.; Klimkowicz-Pawlas, A. Potential ecological risk assessment and predicting zinc accumulation in soils. Environ. Geochem. Health 2017, 40, 435-450. [CrossRef]

21. Sonoda, K.; Hashimoto, Y.; Wang, S.-L.; Ban, T. Copper and zinc in vineyard and orchard soils at millimeter vertical resolution. Sci. Total. Environ. 2019, 689, 958-962. [CrossRef]

22. Babcsányi, I.; Pham, N.T.H.; Balling, P.; Tobak, Z.; Farsang, A. Accumulation of Micronutrients (Cu, Zn) in Vineyard Soils and Transport via Soil Erosion. Available online: https://meetingorganizer.copernicus.org/ EGU2020/EGU2020-21339.html (accessed on 29 July 2020).

23. Gil, C.; Boluda, R.; Ramos-Miras, J.J.; Gil, C. Determination and evaluation of cadmium, lead and nickel in greenhouse soils of Almería (Spain). Chemosphere 2004, 55, 1027-1034. [CrossRef]

24. Micó, C.; Peris, M.; Recatalá, L.; Sánchez, J. Baseline values for heavy metals in agricultural soils in an European Mediterranean region. Sci. Total Environ. 2007, 378, 13-17. [CrossRef]

25. Alloway, B.J. Heavy Metals in Soils, 2nd ed.; Blackie Academic and Professional: London, UK, 1995.

26. Montagne, D.; Cornu, S.; Bourennane, H.; Baize, D.; Ratié, C.; King, D. Effect of Agricultural Practices on Trace Element Distribution in Soil. Commun. Soi. Sci. Plant Anal. 2007, 38, 473-491. [CrossRef]

27. Li, J.; Lu, Y.; Yin, W.; Gan, H.; Zhang, C.; Deng, X.; Lian, J. Distribution of heavy metals in agricultural soils near a petrochemical complex in Guangzhou, China. Environ. Monit. Assess. 2008, 153, 365-375. [CrossRef]

28. Komárek, M.; Száková, J.; Rohošková, M.; Javorská, H.; Chrastný, V.; Balík, J. Copper contamination of vineyard soils from small wine producers: A case study from the Czech Republic. Geoderma 2008, 147, 16-22. [CrossRef]

(C) 2020 by the authors. Licensee MDPI, Basel, Switzerland. This article is an open access article distributed under the terms and conditions of the Creative Commons Attribution (CC BY) license (http://creativecommons.org/licenses/by/4.0/). 